\title{
Haematological alterations due to typhoid fever in Enugu Urban- Nigeria
}

\author{
Okafor, A.I. \\ Department of animal and environmental biology, Abia State University, Uturu- Nigeria \\ E-mail: tconnection68@yahoo.com
}

\begin{abstract}
Some specific haematological changes that accompany chronic and severe typhoid fever were investigated in an endemic area of Enugu Urban-Nigeria. The results established that typhoid fever infections led to a statistically significant leucopenia $(\mathrm{p}<0.05)$. In acute, chronic cases, leucopenia is accompanied with significant oligocythaemia, thrombocytopenia, anaemia and lowered haematocrit $(p<0.05)$. The importance of the results in the diagnosis and treatment of typhoid fever are discussed.
\end{abstract}

Keywords: typhoid fever, haematological, Salmonella typhi.

\section{INTRODUCTION}

Typhoid fever is an acute infection of the blood and intestinal systems caused by the bacterium, Salmonella typhi (Turk and Porter, 1982). An individual gets infected with S. typhi which subsequently develops into typhoid fever by swallowing the bacteria (Toohey, 1976). Consequently the bacilli are spread via contaminated food, drink or water. In other words, the disease transmission pathway can be referred to as the "faecal oral" route. Typhoid fever therefore usually arises due to lack of personal hygiene. It is common in places where there is poor sanitation, but especially where the water supply is liable to be contaminated by human excreta.

Following ingestion, there is an incubation period of about 10 to 14 days (Jawetz et al., 1976). At this period the bacteria move from the intestine, through the blood (where they multiply) and spread to the intestinal lymph nodes, gall bladder, liver, spleen etc (Turk and Porter, 1982; Rene and Pines, 2002). However, their main place of settlement is in the intestine where they cause inflammation and ulcers. (Rene and Pines, 2002). Thus there is often a lesion in the intestinal tract with the consequent danger of haemorrhage and intestinal perforation (Turk and Porter, 1982) Perforation of the intestine which is followed by the leakage of the intestinal contents into the abdominal cavity (peritonitis) is a frequent cause of death from typhoid fever. (Rene and Pines, 2002).

Typhoid fever is clinically manifested by a continued fever, headache, constipation (at first) extreme fatigue, joint pain, splenomegaly, inflammation of the intestine with the formation of intestinal ulcers, a characteristic rose-spot eruption on the abdomen, toxaemia etc. (Top, 1968; Jawetz et al., 1976, Fuller, 2001) If the typhoid becomes chronic and acute, most of the above symptoms manifest one after the other and may, infact, lead to septicaemia. (Cruickshank et al., 1973).

Since the bacilli are found in the blood, faeces and urine of both the ill persons and asymptomatic carriers, diagnosis may be confirmed by laboratory tests that include isolation of S. typhi from blood, stool and urine specimens and by specific agglutination of $S$. typhi with the patient's blood serum known as widal reaction (Levine et al., 1978; Stephen et al., 1984; Pong and Puthucheary, 1989; Schwartz, 2000; Chew et al., 1992).

Paratyphoid fever is another human infectious disease similar to typhoid fever caused by some bacteria that closely resemble $S$. typhi such as $S$. enteritidis var paratyphi or var shottmuelleri.

Based on the easy multiplication of Salmonella spp in the blood stream, this paper aims to determine precisely some specific haematological changes that accompany acute and chronic typhoid fever in Enugu Urban where there is evidence of the disease prevalence. (Umeh, 2004) The information obtained may serve as useful guidelines in arriving at a better diagnosis and treatment of the disease in endemic areas such as Enugu and elsewhere and whilst carrying out further related studies.

\section{MATERIALS AND METHODS}

From January 6, 2006 to January 16, 2007172 blood samples were collected from different adult individuals who came to St. Rita's laboratory at Emene - Enugu to be screened of both typhoid fever and Malaria parasites respectively.

By the use of $5 \mathrm{~mL}$ disposable syringes about $3 \mathrm{~mL}$ of blood were drawn from the veins of the arms of each person and transferred into $5 \mathrm{ml}$ test tube which already contained $0.05 \mathrm{~g}$ of potassium oxalate as anti-coagulant.

About $1 \mathrm{~mL}$ of this blood was used to screen for typhoid fever and malaria parasites using the widal test and light microscope respectively (Levine et al., 1978; Stephen et al., 1984; Pong and Puthucheary, 1989; Chew et al., 1992) Only the blood samples of 19 patients who had typhoid fever without malaria were used for further tests. Typhoid positive serum was taken as that

\section{*Corresponding author}


with visible agglutination at $\geq 1: 160$ dilution. (Levine et al., 1978; Nwaugo et al., 2005).

Blood samples were also got from 119 student volunteers of Enugu State University of Science and Technology (ESUT) Enugu who did not complain of symptoms of malaria or typhoid fever. However $1 \mathrm{ml}$ each of their blood samples were also screened for typhoid fever and malaria parasites respectively and only 68 of those samples that had neither typhoid nor malaria were used as control for typhoid.

From about $2 \mathrm{~mL}$ of blood remaining in each blood sample (typhoid and non-typhoid) the RBC, WBC and platelet counts as well as haemoglobin contents and haematocrit values were determined, following the methods of Baker and Silverton (1982).

Thus, a very small quantity of each blood sample was diluted with one of the RBC diluting fluids, Formol citrate (sodium citrate $3.0 \mathrm{~g}$; Formaldehyde $1.0 \mathrm{~mL}$; and distilled water $100.0 \mathrm{~mL}$ ) in the ratio of $1: 250$. Thus by the use of a haemoglobin pipette, $0.02 \mathrm{~mL}$ of blood were drawn from the test tube and washed into $5.0 \mathrm{~mL}$ of formol citrate contained in a bijou bottle.

The mixture was loaded into a special glass counting chamber, the improved Neubauer haemocytometer. The erythrocytes were allowed to settle for 5 min before their number was counted with the aid of light microscope. Duplicate counts were made for each blood sample and the mean taken. The number of erythrocytes was calculated and recorded (Baker and Silverton, 1982).

The second part each blood sample was diluted with Turk's solution (1\% glacial acetic acid) in the ratio of 1:20. Thus $0.05 \mathrm{~mL}$ of blood was drawn with a haemoglobin pipette from a test tube into $1.0 \mathrm{~mL}$ of Turk's solution contained in a bijou bottle. This mixture was loaded into the improved Neubauer haemocytometer, already used for erythrocytes. The number of leucocytes present in ruled areas meant for counting only the leucocytes was recorded. The leucocyte number was calculated and recorded (Baker and Silverton, 1982).

The third part of each blood sample was diluted with $1 \%$ ammonium oxalate in the ratio of 1:20. Again, by the use of a haemoglobin pipette, $0.02 \mathrm{~mL}$ of blood were drawn from the test tube and washed into $0.4 \mathrm{~mL}$ of $1 \%$ ammonium oxalate contained in a bijou bottle. The mixture was loaded into the Improved Neubauer haemocytometer used for erythrocytes and leucocytes. The platelets were allowed to settle for 5 min before their number was counted with the aid of phase contrast microscope. Duplicate counts were made for each blood sample and the average taken. The number of platelets was calculated and recorded (Baker and Silverton, 1982).

About $1.0 \mathrm{~mL}$ of the remaining blood sample was drawn into a wintrobe microhaematocrit tube which was graduated from 0 to $100 \mathrm{~mm}$ and filled up to the $100 \mathrm{~mm}$ mark. The tube was centrifuged at 3000 revolutions per minute in a Gallenkamp centrifuge for $30 \mathrm{~min}$. The height of the resulting column of packed blood cells was read from the millimeter reading graduations and expressed as the percentage of blood cells within the whole blood or packed cell volume (PCV) (Wintrobe, 1961).
A small volume of the remaining sample of blood was diluted with modified Drabkin's fluid (Potassium cyanide $0.2 \mathrm{~g}$; Potassium ferricyanide $0.2 \mathrm{~g}$; Sodium bicarbonate $1.0 \mathrm{~g}$ and the whole mixture was made up to $1 \mathrm{~L}$ of solution using distilled water) in the ratio of $1: 250$. In other words $0.02 \mathrm{~mL}$ of the blood sample was mixed with $5.0 \mathrm{~mL}$ of Drabkins fluid of $\mathrm{pH} 7.0$. Then about $1.0 \mathrm{~mL}$ of this mixture was poured into a cuvette and its optical Density (O.D) read in a photoelectric colorimeter at absorbance of $540 \mathrm{~nm}$, zeroing with blank. The haemoglobin content of each blood sample was calculated following the methods of Hester and Girling (1991) and Chinyere and Nwachukwu (2001).

$\begin{array}{lll}\mathrm{Hb} 4 & =\frac{\mathrm{T} \times \mathrm{C} \times \mathrm{D}}{\mathrm{A} \times 1000 \mathrm{~g} / 100 \mathrm{~mL}} \\ \text { Where } & \\ \mathrm{T} & = & \text { test absorbance at } 540 \mathrm{~nm} \\ \mathrm{~A} & = & \text { standard absorbance at } 540 \mathrm{~nm} \\ \mathrm{C} & = & \text { concentration of cyanmethaemoglobin } \\ \mathrm{D} & \text { standard }(\mathrm{mg} / 100 \mathrm{~mL}) . \\ 1000 & = & \text { Dilution factor }=250 \\ & \text { converts } \mathrm{mg} / 100 \mathrm{~mL} \text { to } \mathrm{g} / 100 \mathrm{~mL} .\end{array}$

\section{RESULTS}

The mean differences between haematological values obtained for typhoid patients were compared with those of non-typhoid individuals. It was found that typhoid fever led to a statistically significant leucopenia ( $p<0.01$ ), which is in the reduction of White Blood Cells (WBC) Red Blood Cells (RBC) Blood Platelet counts as well as haemoglobin contents and PCV $(p<0.05)$ (Tables 1 and 2)s In more severe and chronic cases, leucopenia is accompanied with thrombocytopenia $(p<0.05)$ oligocythaemia $(p<0.05)$ hypohaemoglobinaemia ( $p$ $<0.05)$ and reduced haematocrit $(p<0.05)$.

\section{DISCUSSION}

The significant leucopenia commonly observed in typhoid fever is attributed to invasion of haemopoietic organs such as lymph nodes, spleen, tonsils, bone marrow etc by $S$. typhi which radically slowed down the rate of leucopoiesis. The invasion of the above organs by $S$. typhi which can also depress the rate of haematopoiesis may also explain the observed oligocythaemia and thrombocytopenia seen in typhoid patients. Thrombocytopenia results in generating spontaneous bruises and prolonged bleeding lesions in the intestinal tract with the consequent danger of haemorrhage and intestinal perforations.

The observed oligocythaemia and hypohaemoglobinemia tend to explain why most acute and chronic typhoid fever cases usually lead to iron deficiency anaemia. (Lucas and Gilles, 1989). 
Mal. J. Microbiol. Vol 3(2) 2007, pp.19-22

Table 1: Haematological data observed amongst 68 nontyphoid persons in Enugu Urban, Nigeria.

\begin{tabular}{|c|c|c|c|c|c|c|}
\hline Sp & RBCC & WBCC & B.PC & $\mathrm{Hb}_{4} \mathrm{C}$ & Hct & Sex \\
\hline $\mathrm{A}_{1}$ & 5.6 & 8.0 & 250 & 16.5 & 51 & $M$ \\
\hline $\mathrm{B}_{1}$ & 5.2 & 9,5 & 300 , & 14.6 & 45 & $M$ \\
\hline $\mathrm{C}_{1}$ & 5.5 & 7.0 & 180 , & 17.4 & 53 & $\mathrm{M}$ \\
\hline $\mathrm{D}_{1}$ & 5.4 & 9.0 & 280 , & 15.3 & 46 & $\mathrm{M}$ \\
\hline $\mathrm{E}_{1}$ & 4.5 & 10.5 & 380 , & 13.8 & 42 & $\mathrm{~F}$ \\
\hline $\mathrm{F}_{1}$ & 5.7 & 9.5 & 320 , & 15.4 & 47 & $M$ \\
\hline $\mathrm{G}_{1}$ & 5.5 & 9.0 & 300 , & 14.8 & 45 & M \\
\hline $\mathrm{H}_{1}$ & 4.9 & 5.0 & 250 , & 13.6 & 41 & $\mathrm{~F}$ \\
\hline$I_{1}$ & 4.8 & 10.5 & 350 , & 13.9 & 42 & $F$ \\
\hline $\mathrm{J}_{1}$ & 5.1 & 8.0 & 150 & 14.0 & 43 & $F$ \\
\hline $\mathrm{K}_{1}$ & 4.9 & 10.0 & 350 , & 13.5 & 41 & $\mathrm{~F}$ \\
\hline $\mathrm{L}_{1}$ & 5.0 & 10.5 & 280 & 16.5 & 50 & $M$ \\
\hline $\mathrm{M}_{1}$ & 4.8 & 8.5 & 330 & 13.8 & 43 & $F$ \\
\hline $\mathrm{N}_{1}$ & 5.5 & 9.0 & 500 & 14.2 & 44 & $\mathrm{~F}$ \\
\hline $\mathrm{O}_{1}$ & 5.1 & 11.0 & 450 , & 16.8 & 52 & $M$ \\
\hline$P_{1}$ & 6.0 & 8.0 & 340 , & 14.6 & 44 & $M$ \\
\hline $\mathrm{Q}_{1}$ & 5.8 & 9.2 & 200 , & 15.7 & 48 & $M$ \\
\hline $\mathrm{R}_{1}$ & 5.4 & 9.5 & 350 , & 14.5 & 44 & $\mathrm{~F}$ \\
\hline $\mathrm{S}_{1}$ & 4.7 & 9.0 & 300 , & 14.0 & 41 & $F$ \\
\hline $\mathrm{T}_{1}$ & 5.3 & 9.0 & 250 , & 14.8 & 45 & $F$ \\
\hline$U_{1}$ & 4.8 & 9.0 & 400 & 13.9 & 43 & $F$ \\
\hline $\mathrm{V}_{1}$ & 4.7 & 8.5 & 380 , & 13.8 & 42 & $F$ \\
\hline$W_{1}$ & 4.5 & 8.5 & 350 , & 13.6 & 41 & $\mathrm{~F}$ \\
\hline $\mathrm{X}_{1}$ & 4.8 & 10.0 & 400 & 14.1 & 40 & $\mathrm{~F}$ \\
\hline$Y_{1}$ & 5.5 & 10.5 & 420 , & 15.5 & 49 & $M$ \\
\hline $\mathrm{Z}_{1}$ & 5.9 & 11.0 & 400 & 15.9 & 50 & $\mathrm{M}$ \\
\hline$A_{3}$ & 5.8 & 10.5 & 350 , & 15.8 & 51 & $\mathrm{M}$ \\
\hline $\mathrm{B}_{3}$ & 5.1 & 10.0 & 360 , & 15.1 & 51 & $\mathrm{M}$ \\
\hline $\mathrm{C}_{3}$ & 5.4 & 9.5 & 350 , & 15.4 & 51 & $M$ \\
\hline$D_{3}$ & 4.4 & 8.5 & 280 & 13.6 & 46 & $\mathrm{~F}$ \\
\hline $\mathrm{E}_{3}$ & 4.6 & 8.0 & 250 & 13.7 & 47 & $\mathrm{~F}$ \\
\hline $\mathrm{F}_{3}$ & 5.3 & 9.0 & 350 , & 15.3 & 51 & $M$ \\
\hline $\mathrm{G}_{3}$ & 5.1 & 9.0 & 330 , & 15.1 & 50 & $\mathrm{M}$ \\
\hline $\mathrm{H}_{3}$ & 4.9 & 8.5 & 310 , & 15.0 & 49 & $\mathrm{M}$ \\
\hline $\mathrm{I}_{3}$ & 5.8 & 10.0 & 350 , & 15.8 & 51 & $\mathrm{M}$ \\
\hline $\mathrm{J}_{3}$ & 4.7 & 8.0 & 280 & 14.9 & 52 & $\mathrm{M}$ \\
\hline $\mathrm{K}_{3}$ & 5.7 & 9.5 & 400 & 15.7 & 54 & $\mathrm{M}$ \\
\hline $\mathrm{L}_{3}$ & 5.6 & 9.0 & 280 & 15.6 & 53 & $\mathrm{M}$ \\
\hline $\mathrm{M}_{3}$ & 5.9 & 9.5 & 320 , & 16.2 & 53 & $M$ \\
\hline $\mathrm{N}_{3}$ & 5.8 & 9.0 & 240 & 16.1 & 52 & $M$ \\
\hline $\mathrm{O}_{3}$ & 6.0 & 10.0 & 500 & 16.4 & 54 & $\mathrm{M}$ \\
\hline$P_{3}$ & 5.0 & 8.0 & 300 , & 14.6 & 45 & $\mathrm{M}$ \\
\hline $\mathrm{Q}_{3}$ & 5.1 & 8.5 & 280 & 14.8 & 45 & $\mathrm{M}$ \\
\hline $\mathrm{R}_{3}$ & 5.4 & 8.5 & 350 , & 15.4 & 46 & $\mathrm{~F}$ \\
\hline $\mathrm{S}_{3}$ & 4.7 & 7.0 & 250 & 14.0 & 44 & $\mathrm{~F}$ \\
\hline $\mathrm{T}_{3}$ & 5.5 & 11.0 & 300 , & 15.5 & 55 & $\mathrm{M}$ \\
\hline $\mathrm{U}_{3}$ & 4.9 & 8.0 & 240 & 14.5 & 42 & $\mathrm{~F}$ \\
\hline$V_{3}$ & 5.5 & 8.5 & 330 , & 14.8 & 48 & $M$ \\
\hline$W_{3}$ & 5.3 & 8.0 & 320 , & 15.5 & 53 & $\mathrm{~F}$ \\
\hline$x_{3}$ & 5.7 & 9.5 & 330 , & 15.7 & 57 & $M$ \\
\hline$Y_{3}$ & 5.6 & 9.0 & 310 , & 15.6 & 56 & $\mathrm{M}$ \\
\hline$Z_{3}$ & 5.5 & 9.5 & 300 & 15.5 & 53 & $\mathrm{M}$ \\
\hline$A_{5}$ & 4.7 & 9.0 & 200 & 14.3 & 41 & $\mathrm{~F}$ \\
\hline $\mathrm{B}_{5}$ & 4.9 & 8.5 & 350 , & 14.4 & 43 & $\mathrm{~F}$ \\
\hline $\mathrm{C}_{5}$ & 4.6 & 8.0 & 300 , & 14.1 & 42 & $F$ \\
\hline $\mathrm{D}_{5}$ & 5.1 & 10.5 & 320 , & 14.6 & 44 & $F$ \\
\hline
\end{tabular}

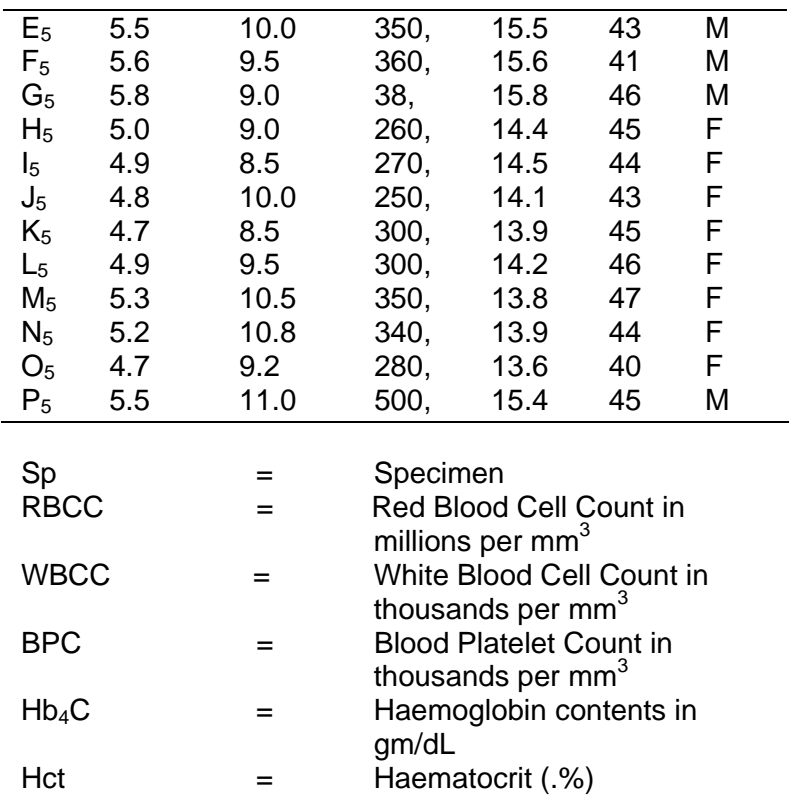

Table 2: Haematological data observed amongst 51 typhoid patients in Enugu Urban, Nigeria.

\begin{tabular}{lllllll}
\hline Sp & RBCC & WBCC & B.PC & Hb4C & Hct & Sex \\
\hline $\mathrm{A}_{2}$ & 4.3 & 3.6 & 130, & 10.2 & 31 & $\mathrm{M}$ \\
$\mathrm{B}_{2}$ & 3.5 & 2.9 & 120, & 9.6 & 30 & $\mathrm{~F}$ \\
$\mathrm{C}_{2}$ & 3.4 & 3.7 & 180, & 8.8 & 29 & $\mathrm{~F}$ \\
$\mathrm{D}_{2}$ & 4.1 & 3.4 & 100, & 10.6 & 32 & $\mathrm{M}$ \\
$\mathrm{E}_{2}$ & 3.9 & 3.8 & 95, & 10.4 & 32 & $\mathrm{M}$ \\
$\mathrm{F}_{2}$ & 3.8 & 3.6 & 90, & 10.6 & 34 & $\mathrm{M}$ \\
$\mathrm{G}_{2}$ & 3.8 & 3.5 & 110, & 8.5 & 29 & $\mathrm{~F}$ \\
$\mathrm{H}_{2}$ & 3.6 & 3.0 & 140, & 9.7 & 30 & $\mathrm{~F}$ \\
$\mathrm{I}_{2}$ & 4.4 & 2.6 & 135, & 11.0 & 35 & $\mathrm{M}$ \\
$\mathrm{J}_{2}$ & 4.0 & 3.0 & 95, & 9.9 & 30 & $\mathrm{M}$ \\
$\mathrm{K}_{2}$ & 3.6 & 2.2 & 120, & 9.0 & 29 & $\mathrm{~F}$ \\
$\mathrm{~L}_{2}$ & 4.1 & 2.8 & 115, & 10.1 & 32 & $\mathrm{M}$ \\
$\mathrm{M}_{2}$ & 3.6 & 3.0 & 80, & 9.4 & 29 & $\mathrm{~F}$ \\
$\mathrm{~N}_{2}$ & 3.9 & 2.5 & 120, & 10.3 & 33 & $\mathrm{M}$ \\
$\mathrm{O}_{2}$ & 3.7 & 2.9 & 125, & 8.5 & 28 & $\mathrm{~F}$ \\
$\mathrm{P}_{2}$ & 3.5 & 2.6 & 110, & 8.8 & 29 & $\mathrm{~F}$ \\
$\mathrm{Q}_{2}$ & 4.2 & 3.4 & 105, & 10.4 & 35 & $\mathrm{M}$ \\
$\mathrm{R}_{2}$ & 3.9 & 3.2 & 100, & 9.8 & 32 & $\mathrm{M}$ \\
$\mathrm{S}_{2}$ & 3.2 & 2.5 & 100, & 8.3 & 28 & $\mathrm{~F}$ \\
$\mathrm{~T}_{2}$ & 3.3 & 2.8 & 105, & 8.9 & 29 & $\mathrm{~F}$ \\
$\mathrm{U}_{2}$ & 3.1 & 3.0 & 85, & 9.1 & 27 & $\mathrm{~F}$ \\
$\mathrm{~V}_{2}$ & 3.5 & 1.8 & 80, & 8.8 & 31 & $\mathrm{~F}$ \\
$\mathrm{~W}_{2}$ & 4.1 & 2.4 & 120, & 10.1 & 32 & $\mathrm{M}$ \\
$\mathrm{X}_{2}$ & 3.9 & 2.2 & 125, & 10.3 & 35 & $\mathrm{M}$ \\
$\mathrm{Y}_{2}$ & 3.8 & 2.6 & 135, & 10.5 & 34 & $\mathrm{M}$ \\
$\mathrm{Z}_{2}$ & 3.8 & 3.4 & 130, & 10.3 & 35 & $\mathrm{M}$ \\
$\mathrm{A}_{4}$ & 4.2 & 2.2 & 115, & 10.2 & 33 & $\mathrm{M}$ \\
$\mathrm{B}_{4}$ & 3.6 & 2.6 & 85, & 9.2 & 29 & $\mathrm{~F}$ \\
$\mathrm{C}_{4}$ & 3.1 & 2.0 & 100, & 9.8 & 28 & $\mathrm{~F}$ \\
$\mathrm{D}_{4}$ & 3.4 & 2.5 & 90, & 9.1 & 30 & $\mathrm{~F}$ \\
$\mathrm{E}_{4}$ & 3.3 & 2.0 & 95, & 8.9 & 33 & $\mathrm{~F}$ \\
\hline & & & & & &
\end{tabular}




\begin{tabular}{|c|c|c|c|c|c|c|}
\hline $\mathrm{F}_{4}$ & 3.5 & 2.4 & 90, & 9.0 & 31 & $\mathrm{~F}$ \\
\hline $\mathrm{G}_{4}$ & 3.4 & 3.0 & 110, & 11.2 & 26 & $\mathrm{~F}$ \\
\hline $\mathrm{H}_{4}$ & 4.0 & 2.6 & 130, & 12.8 & 37 & M \\
\hline $\mathrm{I}_{4}$ & 4.1 & 1.8 & 125 , & 10.5 & 36 & M \\
\hline $\mathrm{J}_{4}$ & 4.2 & 2.1 & 130, & 10.1 & 35 & M \\
\hline $\mathrm{K}_{4}$ & 3.6 & 2.4 & 105, & 9.3 & 34 & $\mathrm{~F}$ \\
\hline $\mathrm{L}_{4}$ & 3.9 & 2.6 & 120, & 10.8 & 36 & M \\
\hline$M_{4}$ & 3.8 & 2.8 & 80, & 9.5 & 30 & $\mathrm{~F}$ \\
\hline $\mathrm{N}_{4}$ & 3.2 & 2.0 & 95, & 8.7 & 34 & $\mathrm{~F}$ \\
\hline $\mathrm{O}_{4}$ & 4.0 & 2.5 & 115 , & 12.8 & 40 & M \\
\hline $9_{4}$ & 4.1 & 2.4 & 125, & 11.5 & 36 & M \\
\hline $\mathrm{Q}_{4}$ & 3.5 & 2.3 & 90 & 9.0 & 30 & $\mathrm{~F}$ \\
\hline R4 & 3.2 & 2.4 & 105, & 9.2 & 30 & $\mathrm{~F}$ \\
\hline S4 & 2.9 & 2.7 & 95, & 9.6 & 29 & $\mathrm{~F}$ \\
\hline T4 & 3.3 & 3.0 & 115, & 9.4 & 29 & $\mathrm{~F}$ \\
\hline U4 & 3.0 & 2.6 & 105, & 8.9 & 32 & $\mathrm{~F}$ \\
\hline v4 & 3.1 & 3.3 & 100, & 9.1 & 30 & $F$ \\
\hline W4 & 2.8 & 2.9 & 108, & 8.4 & 31 & $\mathrm{~F}$ \\
\hline $\mathrm{X} 4$ & 4.4 & 3.1 & 125, & 10.6 & 37 & M \\
\hline Y4 & 4.0 & 3.2 & 130, & 10.2 & 35 & $\mathrm{M}$ \\
\hline Sp & & $=$ & \multicolumn{4}{|c|}{ Specimen } \\
\hline $\mathrm{RBC}$ & & $=$ & \multicolumn{4}{|c|}{$\begin{array}{l}\text { Red Blood Cell Count in } \\
\text { millions per } \mathrm{mm}^{3}\end{array}$} \\
\hline WB & & $=$ & \multicolumn{4}{|c|}{$\begin{array}{l}\text { White Blood Cell Count in } \\
\text { thousands per } \mathrm{mm}^{3}\end{array}$} \\
\hline BPC & & $=$ & \multicolumn{4}{|c|}{$\begin{array}{l}\text { Blood Platelet Count in } \\
\text { thousands per } \mathrm{mm}^{3}\end{array}$} \\
\hline $\mathrm{Hb}_{4}$ & & $=$ & \multicolumn{4}{|c|}{$\begin{array}{l}\text { Haemoglobin content in } \\
\mathrm{mg} / \mathrm{dL}\end{array}$} \\
\hline Hct & & $=$ & \multicolumn{4}{|c|}{ Haematocrit (.\%) } \\
\hline
\end{tabular}

\section{ACKNOWLEDGEMENT}

The author wishes to acknowledge the technical assistance given to him by Mr. Clement Asomugha a Principal technologist in Biochemistry Department of Abia State University Uturu as well Mr Eddy Onuoha another Principal Technologist in the Department of Veterinary Pathology and Microbiology of the University of Nigeria, Nsukka.

\section{REFERENCES}

Baker, F.J. and Silverton, R.E. (1982). Introduction to Medical Laboratory Technology. $5^{\text {th }}$ ed. Butterworth and Co (Publishers) Ltd. London pp 549.

Chew, S.K., Cnizi, M.S.P., Irim, Y.S. and Monteiro, E.H. (1992). Diagnostic value of the widal test for typhoid fever in Singapore. Jour. Trop. Med. Hygie. 95: 288 $-291$.

Chinyere, G.C. and Nwachukwu, N. (2001) Spectroscopy. In: Introduction to laboratory Techniques for the Life Sciences. Research \& Academic Publishers. Okigwe Nigeria

Cruickshank, R., Duguid, J.P., Marmion, B.P. and Swain, R.H.A. (1973). Medical Microbiology $12^{\text {th }}$ ed. Churchill, Livingstone.
Fuller, J.G. (2001). Fever - the hurt for a New killer virus. Davis Mac Gibbon Publishers, London.

Hester, R.E. and Girling, R.B. (1991). Spectroscopy of Biological molecules. Royal Soc, Cambridge.

Jawetz, E., Melnick, J.L. and Adelberg, E.A. (1976). Review of Medical Microbiology $12^{\text {th }}$ ed. Lange, Los Altos, California.

Levine, M.M., Grados, D., Gilman, R.H., Woodward, W. E., Solisplaza, R. and Waldman, W. (1978). Diagnostic value of Widal test in areas endemic for typhoid fever. Amer. Jour. Trop. Med. Hygie. 27: $795-800$.

Lucas, H.O. and Gilles, H.M. (1989). Preventive Medicine for the Tropics. London Press Publishers, London pp. 46 - 49.

Nwaugo, V.O, Nduka, F.O. and Nwachukwu, N.C. (2005). Concomitant typhoid infection in urinary schistosomiasis in South Eastern Nigeria. Global Journal of Pure and Applied Sciences. 3: 353 - 356.

Pong, T. and Puthucheary, S.D. (1989). False positive widal test in non-typhoid Salmonella infection. South East Asian Journal of Tropical Medicine and Public Health. 20:163 - 165.

Rene, D. and Pines, M. (2002). Health and Diseases In: Time Life International pp 22-23; N. V. Publishers, Netherland 54 - 55.

Schwarz, K. (2000) Preventive Medicine in Medical Care. H. K. Lewis and Co. Publishers, New York.

Stephen, A.K., James, J.J., Fredesick, S.B. and Phillip, C.C. (1984). Typhoid fever, An epidemic with remarkably few clinical signs and symptoms. Annals of Internal medicine 144: 533 - 537.

Toohey, A. (1976) Medicine for Nurses. London Press Publishers London pp. 59 - 64.

Top, F.H. (1968) Communicable and Infectious Diseases $6^{\text {th }}$ ed. Mosby. St. Louis.

Turk, D.C. and Porter, I.A. (1982). Medical Microbiology $3^{\text {rd }}$ ed. English Universities Press Ltd pp. 30-35.

Umeh, C.K. (2004). Haematological changes in Typhoid fever patients. B.Sc thesis, Abia State University, Uturu Nigeria.

Wintrobe, M.M. (1961). Clinical Haematology $5^{\text {th }}$ ed. W.B. Saunders. Co. Philadelphia. 